\title{
Phylogenetic relationships within the family Halomonadaceae based on comparative $23 S$ and 16S rRNA gene sequence analysis
}

Correspondence Antonio Ventosa ventosa@us.es

\author{
Rafael R. de la Haba, ${ }^{1}$ David R. Arahal, ${ }^{2}$ M. Carmen Márquez ${ }^{1}$ \\ and Antonio Ventosa ${ }^{1}$
}
${ }^{1}$ Department of Microbiology and Parasitology, Faculty of Pharmacy, University of Sevilla, 41012 Sevilla, Spain
${ }^{2}$ Spanish Type Culture Collection (CECT) and Department of Microbiology and Ecology, University of Valencia, 46100 Valencia, Spain

\begin{abstract}
A phylogenetic study of the family Halomonadaceae was carried out based on complete $16 \mathrm{~S}$ rRNA and 23S rRNA gene sequences. Several 16S rRNA genes of type strains were resequenced, and 28 new sequences of the $23 S$ rRNA gene were obtained. Currently, the family includes nine genera (Carnimonas, Chromohalobacter, Cobetia, Halomonas, Halotalea, Kushneria, Modicisalibacter, Salinicola and Zymobacter). These genera are phylogenetically coherent except Halomonas, which is polyphyletic. This genus comprises two clearly distinguished clusters: group 1 includes Halomonas elongata (the type species) and the species Halomonas eurihalina, $H$. caseinilytica, $H$. halmophila, $H$. sabkhae, $H$. almeriensis, $H$. halophila, $H$. salina, $H$. organivorans, $H$. koreensis, $H$. maura and $H$. nitroreducens. Group 2 comprises the species Halomonas aquamarina, $H$. meridiana, $H$. axialensis, $H$. magadiensis, $H$. hydrothermalis, $H$. alkaliphila, $H$. venusta, $H$. boliviensis, $H$. neptunia, $H$. variabilis, $H$. sulfidaeris, $H$. subterranea, $H$. janggokensis, $H$. gomseomensis, $H$. arcis and $H$. subglaciescola. Halomonas salaria forms a cluster with Chromohalobacter salarius and the recently described genus Salinicola, and their taxonomic affiliation requires further study. More than $20 \mathrm{Halomonas} \mathrm{species} \mathrm{are} \mathrm{phylogenetically}$ not within the core constituted by the Halomonas sensu stricto cluster (group 1) or group 2 and, since their positions on the different phylogenetic trees are not stable, they cannot be recognized as additional groups either. In general, there is excellent agreement between the phylogenies based on the two rRNA gene sequences, but the 23S rRNA gene showed higher resolution in the differentiation of species of the family Halomonadaceae.
\end{abstract}

The family Halomonadaceae forms a separate phylogenetic lineage within the Gammaproteobacteria according to $16 \mathrm{~S}$ rRNA gene sequence analysis and is made up mostly of halophilic bacteria. Since its creation in 1988 (Franzmann et al., 1988), the taxonomy of the family has been under continuous revision. At the time of writing, the family Halomonadaceae comprises nine genera, the most prominent being Halomonas, which contains 55 species, and Chromohalobacter, with nine species. Six genera are currently represented by single species; these are Zymobacter palmae (Okamoto et al., 1993), Carnimonas nigricans (Garriga et al., 1998; Arahal et al., 2002b), Cobetia marina (Arahal et al., 2002a), Halotalea alkalilenta (Ntougias et al., 2007),

The GenBank/EMBL/DDBJ accession numbers for the newly reported 16S and 23S rRNA gene sequences are detailed in Table 1.

Maximum-parsimony and maximum-likelihood trees based on $16 \mathrm{~S}$ and 23S rRNA gene sequences are available as supplementary material with the online version of this paper.
Modicisalibacter tunisiensis (Ben Ali Gam et al., 2007) and Salinicola socius (Anan'ina et al., 2007, 2008). Very recently, Sánchez-Porro et al. (2009) described the new genus Kushneria, which currently consists of four species, the novel species Kushneria aurantia as well as three species that were previously assigned to the genus Halomonas, Kushneria avicenniae, K. indalinina and K. marisflavi.

Arahal et al. (2002b) carried out a study of the phylogeny of species of the family Halomonadaceae whose names were validly published at that time (a total of 25) using comparative sequence analysis of the $23 \mathrm{~S}$ and 16S rRNA genes. Since then, 49 novel species have been described and, in some cases, their phylogenetic relationships are not clearly established. The purpose of this article was to determine in detail the phylogenetic relationships of the species of the genera of the family Halomonadaceae and to clarify the current classification of this heterogeneous bacterial family using a comparative analysis based on $23 \mathrm{~S}$ and 16S rRNA 
gene sequences. Moreover, following the recommended minimal standards for the description of new members of the family Halomonadaceae, seven already-sequenced $16 \mathrm{~S}$ rRNA genes of type strains have been sequenced again to resolve undetermined positions and to reach the established quality standards (Arahal et al., 2007). In addition, 28 new complete 23S rRNA gene sequences have been obtained on this study. Finally, some suggestions are included about the recommended sequences to be used for future comparative phylogenetic analysis.

All strains used in this study were type strains of species with validly published names within the family Halomonadaceae. Most (23 strains) originated from culture collections and the rest (seven strains) were obtained directly from the authors that proposed them as types of novel species (Table 1). Strains were cultivated following the media and growth conditions recommended by the culture collections or the donor authors.

Chromosomal DNA was isolated and purified according to the following protocol. Cells were collected from $3 \mathrm{ml}$ of an exponentially growing broth culture by centrifugation at 12000 r.p.m. for $2 \mathrm{~min}$ and the pellet was resuspended in $558 \mu \mathrm{l}$ TE buffer ( $\mathrm{pH} 8.0$ ). After that, $30 \mu \mathrm{l} 10 \%$ (w/v) SDS, $6 \mu$ l proteinase $\mathrm{K}\left(20 \mathrm{mg} \mathrm{ml}^{-1}\right), 6 \mu \mathrm{l}$ RNase $(10 \mathrm{mg}$ $\left.\mathrm{ml}^{-1}\right)$ and $37 \mu \mathrm{l}$ lysozyme $\left(20 \mathrm{mg} \mathrm{ml}^{-1}\right)$ were added and an incubation step was performed at $37^{\circ} \mathrm{C}$ for $30 \mathrm{~min}$. This was followed by a second incubation at $65{ }^{\circ} \mathrm{C}$ for 15 min after the addition of $100 \mu \mathrm{l} 5 \mathrm{M} \mathrm{NaCl}$ and $80 \mu \mathrm{l}$ $10 \%(\mathrm{w} / \mathrm{v})$ CTAB. Next, an equal volume of chloroform/ isoamyl alcohol $(24: 1)$ was added to extract the total DNA. The contents of the tube were mixed vigorously and centrifuged at 12000 r.p.m. for $5 \mathrm{~min}$, and the aqueous fraction was recovered. When necessary, the extraction step was repeated to increase the yield of DNA. Subsequently, 0.6 vols cold isopropyl alcohol was added to precipitate the DNA and the mixture was centrifuged at 13200 r.p.m. for 15 min. Finally, the precipitated DNA was dissolved in $50 \mu \mathrm{TE}$ buffer and checked by agarose gel electrophoresis. The gel was prepared dissolving $1 \%$ agarose (SeaKem) in $1 \times$ TAE buffer by heating. Ethidium bromide $(3 \mathrm{ml}$ of a $10 \mathrm{mg} \mathrm{ml}^{-1}$ solution) was added in order to visualize the genetic material. Each DNA solution $(5 \mu \mathrm{l})$ was mixed with $2 \mu$ loading buffer and loaded onto the gel (Sambrook \& Russell, 2001). A $1 \mathrm{~kb}$ ladder (Invitrogen) was used as a marker.

For PCR amplification, approximately $100 \mathrm{ng}$ total DNA was used with a Taq DNA polymerase kit (Eppendorf) following the recommendations of the manufacturer. The $16 \mathrm{~S}$ rRNA gene was amplified from positions 8 to 1511 of the $16 \mathrm{~S}$ rRNA by using the universal primers 16F27 and 16R1488. To obtain the complete $23 \mathrm{~S}$ rRNA gene, two fragments were amplified, one from positions 12 to 2669 of the $23 \mathrm{~S}$ rRNA gene and another from position 1091 of the $23 \mathrm{~S}$ rRNA to position 49 of the 5S rRNA (Escherichia coli numbering). The 16S and $23 \mathrm{~S}$ rRNA gene nucleotide sequences were determined by NBT-Newbiotechnics (Seville, Spain) using an automated
DNA sequencer model 3130XL (Applied Biosystems) and the sequences were then assembled by using the ChromasPro software (Technelysium) and corrected manually to resolve ambiguous positions. The amplification and sequencing primers used in this study are given in Table 2. Obtained 23S and $16 \mathrm{~S}$ rRNA gene sequences were compared with reference $23 \mathrm{~S}$ and 16S rRNA gene sequences retrieved from the GenBank and EMBL databases by BLAST searching (http:// www.ncbi.nlm.nih.gov/blast/). The subsequent sequence analysis was performed by using the ARB program package (Ludwig et al., 2004).

To construct the final phylogenetic trees, only sequences from type strains of species of the family Halomonadaceae whose names were validly published were taken into account and, when more than one sequence of the same gene and strain was available, only the most complete or the one that contained fewer ambiguous positions was used. The GenBank/EMBL/DDBJ accession numbers for the $16 \mathrm{~S}$ and 23S rRNA gene sequences that were used in this study, which also includes those determined in our laboratory, are listed in Table 1. Sequences were aligned by using FastAligner version 1.03 and the alignments were corrected by hand. A distance matrix was obtained and evolutionary distances were computed using the formula of Jukes \& Cantor (1969). Only sequence positions with $50 \%$ conservation or more within the family Halomonadaceae were taken into account by applying a filter. Evolutionary history was inferred using several treeing methods [maximum-parsimony (Fitch, 1971), neighbour-joining (Saitou \& Nei, 1987) and maximumlikelihood (Felsenstein, 1981)] on the basis of the recommendations of Ludwig et al. (1998). A global optimization of the maximum-parsimony analysis was carried out. A bootstrap test was performed by calculating 1000 replicate trees in order to assess the robustness of the topology. The application of these three treeing methods and changes of outgroups produced nearly identical tree topologies among the members of the family Halomonadaceae. Figs 1 and 2 show representative trees constructed using the neighbourjoining method with the 16S and 23S rRNA gene sequences, respectively. Maximum-parsimony (Supplementary Fig. S1) and maximum-likelihood (Supplementary Fig. S2) trees resulting from $16 \mathrm{~S}$ and $23 \mathrm{~S}$ rRNA gene sequence analyses are available in IJSEM Online.

Phylogenetic analyses of $16 \mathrm{~S}$ rRNA and $23 \mathrm{~S}$ rRNA gene sequences were performed on datasets consisting of 1446 and 2862 nucleotide positions (E. coli positions $24-1501$ and 12904), respectively. The mean similarity scored between the different $16 \mathrm{~S}$ rRNA gene sequences analysed in this study was one unit higher than that of the 23S rRNA gene sequences, suggesting a slower evolutionary rate for the $16 \mathrm{~S}$ fraction of the rRNA gene. It has to be noted that, even in the postgenomic era, the number of publicly available $23 \mathrm{~S}$ rRNA gene sequences is not very large: currently, there are about 12500 complete or almost-complete $23 \mathrm{~S}$ rRNA gene sequences available, whereas this number exceeds 324000 in the case of the $16 \mathrm{~S}$ rRNA gene. A recommended solution is the use of a database of good-quality and aligned sequences of the small 
Table 1. Species of the family Halomonadaceae with validly published names included in this study

Sequences obtained in this study are highlighted in bold. When more than one sequence is available for the same species, we recommend the use of the sequence marked with an asterisk.

\begin{tabular}{|c|c|c|c|c|c|c|c|}
\hline \multirow[t]{2}{*}{ Species } & \multirow[t]{2}{*}{ Reference } & \multicolumn{3}{|c|}{$16 S$ rRNA gene } & \multicolumn{3}{|c|}{ 23S rRNA gene } \\
\hline & & Strain & $\begin{array}{c}\text { Accession } \\
\text { no. }\end{array}$ & $\begin{array}{c}\text { Length } \\
\text { (bp) }\end{array}$ & Strain & $\begin{array}{c}\text { Accession } \\
\text { no. }\end{array}$ & $\begin{array}{c}\text { Length } \\
\text { (bp) }\end{array}$ \\
\hline \multicolumn{8}{|l|}{ Carnimonas } \\
\hline C. nigrificans & Garriga et al. (1998) & $\mathrm{CTCBS}^{\mathrm{T}}$ & Y13299 & 1519 & CECT $4437^{\mathrm{T}}$ & AM941757 & 2913 \\
\hline \multicolumn{8}{|l|}{ Chromohalobacter } \\
\hline C. canadensis & & DSM $6769^{\mathrm{T}}$ & AF211861 & 1495 & & & \\
\hline \multirow[t]{2}{*}{ C. israelensis } & Arahal et al. (2001a) & ATCC $43985^{\mathrm{T}}$ & AJ295144* & 1532 & DSM $6768^{\mathrm{T}}$ & AJ306871 & 2909 \\
\hline & & DSM $6768^{\mathrm{T}}$ & AF211862 & 1492 & & & \\
\hline C. japonicus & Sánchez-Porro et al. (2007) & $43^{\mathrm{T}}$ & AB105159 & 1501 & & & \\
\hline C. marismortui & Ventosa et al. (1989) & ATCC $17056^{\mathrm{T}}$ & X87219 & 1423 & ATCC $17056^{\mathrm{T}}$ & AJ306872 & 2998 \\
\hline \multicolumn{8}{|l|}{ Cobetia } \\
\hline \multirow[t]{2}{*}{ C. marina } & Arahal et al. (2002a) & DSM $4741^{\mathrm{T}}$ & AJ306890* & 1536 & DSM $4741^{\mathrm{T}}$ & AJ306880 & 2910 \\
\hline & & ATCC $25374^{\mathrm{T}}$ & M93354 & 1483 & & & \\
\hline \multicolumn{8}{|l|}{ Halomonas } \\
\hline H. alimentaria & Yoon et al. (2002) & YKJ-16 $6^{\mathrm{T}}$ & AF211860 & 1493 & DSM $15356^{\mathrm{T}}$ & FN257749 & 2908 \\
\hline H. alkaliphila & Romano et al. (2006) & $18 \mathrm{bAG}^{\mathrm{T}}$ & AJ640133 & 1500 & & & \\
\hline H. almeriensis & Martínez-Checa et al. (2005) & $\mathrm{M}^{\mathrm{T}}$ & AY858696 & 1459 & $\mathrm{M8}^{\mathrm{T}}$ & FN257744 & 2909 \\
\hline H. anticariensis & Martínez-Cánovas et al. (2004b) & $\mathrm{FP} 35^{\mathrm{T}}$ & AY489405 & 1464 & $\mathrm{FP}^{2} 5^{\mathrm{T}}$ & FN263244 & 2911 \\
\hline \multirow[t]{2}{*}{ H. aquamarina } & Dobson \& Franzmann (1996) & DSM $30161^{\mathrm{T}}$ & AJ306888* & 1528 & DSM $30161^{\mathrm{T}}$ & AJ306874 & 2914 \\
\hline & & ATCC $14400^{\mathrm{T}}$ & M93352 & 1466 & & & \\
\hline H. arcis & Xu et al. (2007) & $\mathrm{AJ} 282^{\mathrm{T}}$ & EF144147 & 1404 & & & \\
\hline H. cupida & & DSM $4740^{\mathrm{T}}$ & L42615 & 1471 & & & \\
\hline H. daqingensis & Wu et al. (2008b) & DQD2-30 ${ }^{\mathrm{T}}$ & EF121854 & 1420 & & & \\
\hline H. denitrificans & Kim et al. (2007) & $\mathrm{M} 29^{\mathrm{T}}$ & AM229317 & 1489 & & & \\
\hline H. desiderata & Berendes et al. (1996) & $\mathrm{FB} 2^{\mathrm{T}}$ & X92417 & 1495 & DSM $9502^{\mathrm{T}}$ & AJ306876 & 2910 \\
\hline \multirow[t]{3}{*}{ H. elongata } & Vreeland et al. (1980) & ATCC $33173^{\mathrm{T}}$ & AM941743* & 1457 & ATCC $33173^{\mathrm{T}}$ & AJ306877 & 2910 \\
\hline & & ATCC $33173^{\mathrm{T}}$ & $\mathrm{X} 67023$ & 1470 & & & \\
\hline & & $\operatorname{ATCC} 33173^{\mathrm{T}}$ & M93355 & 1479 & & & \\
\hline \multirow[t]{2}{*}{ H. eurihalina } & Mellado et al. (1995) & ATCC $49336^{\mathrm{T}}$ & $\mathrm{X} 87218^{*}$ & 1473 & ATCC $49336^{\mathrm{T}}$ & AJ306878 & 2911 \\
\hline & & ATCC $49336^{\mathrm{T}}$ & L42620 & 1490 & & & \\
\hline H. gomseomensis & Kim et al. (2007) & $\mathrm{M} 12^{\mathrm{T}}$ & AM229314 & 1484 & & & \\
\hline H. gudaonensis & Wang et al. (2007a) & SL014B- $69^{\mathrm{T}}$ & DQ421808 & 1462 & & & \\
\hline \multirow[t]{2}{*}{ H. halmophila } & Dobson et al. (1990) & ATCC $19717^{\mathrm{T}}$ & AJ306889* & 1530 & ATCC $19717^{\mathrm{T}}$ & AJ306879 & 2920 \\
\hline & & ATCC $19717^{\mathrm{T}}$ & M59153 & 1540 & & & \\
\hline H. halocynthiae & Romanenko et al. (2002) & KMM $1376^{\mathrm{T}}$ & AJ417388 & 1514 & DSM $14573^{T}$ & FN257752 & 2908 \\
\hline H. halodenitrificans & Dobson \& Franzmann (1996) & ATCC $13511^{\mathrm{T}}$ & L04942 & 1531 & CECT $5012^{\mathrm{T}}$ & FN257751 & 2908 \\
\hline \multirow[t]{2}{*}{ H. halodurans } & Hebert \& Vreeland (1987) & DSM $5160^{T}$ & FN257743* & 1446 & DSM $5160^{\mathrm{T}}$ & FN257761 & 2910 \\
\hline & & DSM $5160^{\mathrm{T}}$ & L42619 & 1474 & & & \\
\hline
\end{tabular}


Table 1. cont.

\begin{tabular}{|c|c|c|c|c|c|c|c|}
\hline \multirow[t]{2}{*}{ Species } & \multirow[t]{2}{*}{ Reference } & \multicolumn{3}{|c|}{ 16S rRNA gene } & \multicolumn{3}{|c|}{ 23S rRNA gene } \\
\hline & & Strain & $\begin{array}{c}\text { Accession } \\
\text { no. }\end{array}$ & $\begin{array}{l}\text { Length } \\
\text { (bp) }\end{array}$ & Strain & $\begin{array}{c}\text { Accession } \\
\text { no. }\end{array}$ & $\begin{array}{c}\text { Length } \\
\text { (bp) }\end{array}$ \\
\hline \multirow[t]{3}{*}{ H. halophila } & Dobson \& Franzmann (1996) & DSM $4770^{T}$ & FN257740* & 1475 & DSM $4770^{T}$ & FN257745 & 2908 \\
\hline & & CCM $3662^{\mathrm{T}}$ & AM941744 & 1461 & CCM $3662^{\mathrm{T}}$ & AM941750 & 2908 \\
\hline & & DSM $4770^{\mathrm{T}}$ & M93353 & 1478 & & & \\
\hline H. hydrothermalis & Kaye et al. (2004) & Slthf $2^{\mathrm{T}}$ & AF212218 & 1409 & CECT $5814^{\mathrm{T}}$ & AM941749 & 2912 \\
\hline H. janggokensis & Kim et al. (2007) & $\mathrm{M} 24^{\mathrm{T}}$ & AM229315 & 1478 & & & \\
\hline H. kenyensis & Boltyanskaya et al. (2007) & AIR-2 $2^{\mathrm{T}}$ & AY962237 & 1371 & & & \\
\hline H. koreensis & Lim et al. (2004) & $\mathrm{SS} 20^{\mathrm{T}}$ & AY382579 & 1399 & JCM $12237^{\mathrm{T}}$ & FN257747 & 2908 \\
\hline H. korlensis & Li et al. (2008) & $\mathrm{XK} 1^{\mathrm{T}}$ & EU085033 & 1517 & & & \\
\hline H. kribbensis & Jeon et al. (2007) & $\mathrm{BH} 843^{\mathrm{T}}$ & DQ280368 & 1417 & & & \\
\hline H. lutea & Wang et al. (2008a) & YIM $91125^{\mathrm{T}}$ & EF674852 & 1479 & & & \\
\hline H. magadiensis & Duckworth et al. (2000) & $21 \mathrm{MI}^{\mathrm{T}}$ & X92150 & 1473 & $21 \mathrm{MI}^{\mathrm{T}}$ & AM941747 & 2915 \\
\hline \multirow[t]{2}{*}{ H. maura } & Bouchotroch et al. (2001) & $S-31^{T}$ & FN257741* & 1455 & $S-31^{T}$ & FN257746 & 2908 \\
\hline & & $\mathrm{S}-31^{\mathrm{T}}$ & AJ271864 & 1396 & & & \\
\hline \multirow[t]{2}{*}{ H. meridiana } & James et al. (1990) & DSM $5425^{\mathrm{T}}$ & AJ306891* & 1528 & DSM $5425^{\mathrm{T}}$ & AJ306881 & 2914 \\
\hline & & DSM $5425^{\mathrm{T}}$ & M93356 & 1475 & & & \\
\hline H. mongoliensis & Boltyanskaya et al. (2007) & $\mathrm{Z}-7009^{\mathrm{T}}$ & AY962236 & 1372 & & & \\
\hline H. muralis & Heyrman et al. (2002) & LMG $20969^{\mathrm{T}}$ & AJ320530 & 1493 & DSM $14789^{T}$ & FN257757 & 2923 \\
\hline H. neptunia & Kaye et al. (2004) & Eplume $1^{\mathrm{T}}$ & AF212202 & 1454 & CECT $5815^{\mathrm{T}}$ & FN257755 & 2920 \\
\hline H. nitroreducens & González-Domenech et al. (2008a) & $11 S^{T}$ & EF613113 & 1441 & & & \\
\hline H. organivorans & García et al. (2004) & $\mathrm{G}-16.1^{\mathrm{T}}$ & AJ616910 & 1472 & G-16.1 ${ }^{T}$ & AM941751 & 2908 \\
\hline \multirow[t]{2}{*}{ H. pacifica } & Dobson \& Franzmann (1996) & DSM $4742^{\mathrm{T}}$ & L42616* & 1480 & DSM $4742^{\mathrm{T}}$ & AJ306882 & 2910 \\
\hline & & ATCC $27122^{\mathrm{T}}$ & EU373088 & 1449 & & & \\
\hline H. pantelleriensis & Romano et al. (1996) & $\mathrm{AAP}^{\mathrm{T}}$ & X93493 & 1477 & DSM $9661^{\mathrm{T}}$ & AJ306883 & 2912 \\
\hline H. sabkhae & Kharroub et al. (2008) & $5-3^{\mathrm{T}}$ & EF442769 & 1540 & & & \\
\hline H. saccharevitans & $\mathrm{Xu}$ et al. (2007) & $\mathrm{AJ} 275^{\mathrm{T}}$ & EF144149 & 1407 & & & \\
\hline H. salaria & Kim et al. (2007) & $\mathrm{M} 27^{\mathrm{T}}$ & AM229316 & 1492 & & & \\
\hline H. salifodinae & Wang et al. (2008b) & $\mathrm{BC} 7^{\mathrm{T}}$ & EF527873 & 1428 & & & \\
\hline \multirow[t]{5}{*}{ H. salina } & Dobson \& Franzmann (1996) & $\mathrm{F} 8-11^{\mathrm{T}}$ & AJ295145* & 1532 & DSM $5928^{\mathrm{T}}$ & AJ306884 & 2908 \\
\hline & & ATCC $49509^{\mathrm{T}}$ & L42617 & 1443 & & & \\
\hline & & ATCC $49509^{\mathrm{T}}$ & X87217 & 1478 & & & \\
\hline & & ATCC $49509^{\mathrm{T}}$ & AJ243447 & 1493 & & & \\
\hline & & DSM $5928^{\mathrm{T}}$ & AJ243448 & 1493 & & & \\
\hline H. shengliensis & Wang et al. (2007b) & SL014B- $85^{\mathrm{T}}$ & EF121853 & 1460 & & & \\
\hline \multirow[t]{2}{*}{ H. subglaciescola } & Franzmann et al. (1987) & DSM $4683^{\mathrm{T}}$ & AJ306892* & 1531 & DSM $4683^{\mathrm{T}}$ & AJ306885 & 2910 \\
\hline & & DSM $4683^{\mathrm{T}}$ & M93358 & 1481 & & & \\
\hline H. subterranea & Xu et al. (2007) & $\mathrm{ZG} 6^{\mathrm{T}}$ & EF144148 & 1381 & & & \\
\hline H. sulfidaeris & Kaye et al. (2004) & Esulfide $^{\mathrm{T}}$ & AF212204 & 1430 & CECT $5817^{T}$ & AM941748 & 2911 \\
\hline H. taeanensis & Lee et al. (2005) & $\mathrm{BH} 539^{\mathrm{T}}$ & AY671975 & 1408 & $\mathrm{BH} 539^{\mathrm{T}}$ & AY829729 & 2907 \\
\hline \multirow[t]{2}{*}{ H. variabilis } & Dobson \& Franzmann (1996) & DSM $3051^{\mathrm{T}}$ & AJ306893* & 1528 & DSM $3051^{\mathrm{T}}$ & AJ306886 & 2912 \\
\hline & & DSM $3051^{\mathrm{T}}$ & M93357 & 1470 & & & \\
\hline H. ventosae & Martínez-Cánovas et al. (2004a) & $\mathrm{Al} 12^{\mathrm{T}}$ & AY268080 & 1395 & $\mathrm{All}^{\mathrm{T}}$ & FN257748 & 3009 \\
\hline \multirow[t]{2}{*}{ H. venusta } & Dobson \& Franzmann (1996) & DSM $4743^{\mathrm{T}}$ & AJ306894* & 1530 & DSM $4743^{\mathrm{T}}$ & AJ306887 & 2914 \\
\hline & & DSM $4743^{\mathrm{T}}$ & L42618 & 1479 & & & \\
\hline \multicolumn{8}{|l|}{ Halotalea } \\
\hline H. alkalilenta & Ntougias et al. (2007) & $\mathrm{AW}-7^{\mathrm{T}}$ & DQ421388 & 1491 & CECT $7134^{\mathrm{T}}$ & FN257762 & 3018 \\
\hline \multicolumn{8}{|l|}{ Kushneria } \\
\hline K. aurantia & Sánchez-Porro et al. (2009) & $\mathrm{A} 10^{\mathrm{T}}$ & AM941746 & 1428 & $\mathrm{~A} 10^{\mathrm{T}}$ & AM941756 & 2914 \\
\hline K. avicenniae & Sánchez-Porro et al. (2009) & $\mathrm{MW} 2 \mathrm{a}^{\mathrm{T}}$ & DQ888315 & 1433 & $\mathrm{MW} 2 \mathrm{a}^{\mathrm{T}}$ & AM941755 & 2912 \\
\hline \multirow[t]{2}{*}{ K. indalinina } & Sánchez-Porro et al. (2009) & CG2.1 ${ }^{\mathrm{T}}$ & AM941745* & 1478 & CG2.1 $1^{\mathrm{T}}$ & AM941754 & 2913 \\
\hline & & CG $2.1^{\mathrm{T}}$ & AJ427627 & 1527 & & & \\
\hline K. marisflavi & Sánchez-Porro et al. (2009) & $\mathrm{SW} 32^{\mathrm{T}}$ & AF251143 & 1495 & DSM $15357^{\mathrm{T}}$ & AM941753 & 2914 \\
\hline \multicolumn{8}{|l|}{ Modicisalibacter } \\
\hline M. tunisiensis & Ben Ali Gam et al. (2007) & $\mathrm{LIT}^{\mathrm{T}}$ & DQ641495 & 1531 & CIP $109206^{\mathrm{T}}$ & FN257756 & 2909 \\
\hline
\end{tabular}


Table 1. cont.

\begin{tabular}{|c|c|c|c|c|c|c|c|}
\hline \multirow[t]{2}{*}{ Species } & \multirow[t]{2}{*}{ Reference } & \multicolumn{3}{|c|}{ 16S rRNA gene } & \multicolumn{3}{|c|}{$23 S$ rRNA gene } \\
\hline & & Strain & $\begin{array}{c}\text { Accession } \\
\text { no. }\end{array}$ & $\begin{array}{l}\text { Length } \\
\text { (bp) }\end{array}$ & Strain & $\begin{array}{c}\text { Accession } \\
\text { no. }\end{array}$ & $\begin{array}{c}\text { Length } \\
\text { (bp) }\end{array}$ \\
\hline \multicolumn{8}{|l|}{ Salinicola } \\
\hline S. socius & Anan'ina et al. (2007) & $\mathrm{SMB}_{3} 5^{\mathrm{T}}$ & DQ979342 & 1433 & & & \\
\hline \multicolumn{8}{|l|}{ Zymobacter } \\
\hline
\end{tabular}

and large rRNA subunits that can be retrieved from the SILVA rRNA database project (Pruesse et al., 2007).

The 16S and 23S rRNA gene sequence analyses (Figs 1 and 2) demonstrated the phylogenetic distinctness of the family Halomonadaceae. As reported previously (Arahal et al., 2002b), the genus Halomonas is not monophyletic and comprises two clearly separated phylogenetic groups that now contain larger numbers of species. Group 1 is formed by Halomonas elongata (the type species of the genus), $H$. eurihalina, $H$. caseinilytica, $H$. halmophila, $H$. sabkhae, $H$. almeriensis, $H$. halophila, $H$. salina, $H$. organivorans, $H$. koreensis, $H$. maura and $H$. nitroreducens (note that the abbreviation $H$. is used throughout to represent Halomonas; the genus name Halotalea is given in full throughout). The mean $16 \mathrm{~S}$ rRNA gene sequence similarity for this group was $97.8 \%$. A lower value was obtained with the $23 \mathrm{~S}$ rRNA gene sequences (97.0\%). The $16 \mathrm{~S}$ rRNA gene sequence of $H$. halophila DSM $4770^{\mathrm{T}}$ was first determined by Dobson et al. (1993), showing a total of 76 ambiguous positions. A large number of unresolved positions and/or errors may be wrongly taken as evidence of a different species, hence the importance of including only high-quality (almost) complete $16 \mathrm{~S}$ rRNA gene sequences in new taxonomic proposals (Arahal et al., 2007). For this reason, we determined again the almost-complete $16 \mathrm{~S}$ rRNA gene sequences of $H$. halophila strains DSM $4770^{\mathrm{T}}$ and CCM $3662^{\mathrm{T}}$, equivalent designations of the type strain of the species, and newly determined the complete $23 \mathrm{~S}$ rRNA gene sequences of these strains. In this study, the $16 \mathrm{~S}$ and $23 \mathrm{~S}$ rRNA gene sequences of these two strains showed $100 \%$ similarity to the respective sequences of the type strain of $H$. salina. However, although their $16 \mathrm{~S}$ and $23 \mathrm{~S}$ rRNA gene sequences are identical, it has been clearly demonstrated that $H$. halophila and $H$. salina constitute two different Halomonas species on the basis of their phenotypic and genotypic features (Valderrama et al., 1991). This fact reinforces the importance in modern bacterial systematics of

Table 2. Amplification and sequencing primers used in this study

Each forward amplification primer was used together with the reverse primer below it in the table. Sequences are listed according to the IUPAC code for nucleotide ambiguities. Primer positions are given according to the E. coli numbering.

\begin{tabular}{|llcl|}
\hline Primer & \multicolumn{1}{c|}{ Sequence $\left(\mathbf{5}^{\prime} \rightarrow \mathbf{3}^{\prime}\right)$} & Position & Use \\
\hline 16S rRNA gene & & & \\
16F27 & & $8-27$ & Amplification, forward sequencing, 16S rRNA gene \\
16R1488 & AGAGTTTGATCMTGGCTCAG & $1488-1511$ & Amplification, reverse sequencing, 16S rRNA gene \\
16F530 & CGGTTACCTTGTTAGGACTTCACC & $515-530$ & Sequencing, 16S rRNA gene \\
16R343 & GTGCCAGCAGCCGCGG & $358-343$ & Sequencing, 16S rRNA gene \\
23S rRNA gene & ACTGCTGCCTCCCGTA & & \\
23SppioFw & & $-12-7$ & Amplification, forward \\
985R & TTSGGGTTATAKGGTCAAG & $2654-2669$ & Amplification, reverse \\
1023V & CCGGTCCTCTCGTACT & $1091-1105$ & Amplification, forward \\
504R & GCGTAAYAGCTCACT & $35-49$ & Amplification, reverse \\
992IRry97 & SWGTTCGRVAWGGGA & $457-471$ & Sequencing, 23S rRNA gene \\
1020IRrmz98 & TTCCCTCACRGTACT & $975-990$ & Sequencing, 23S rRNA gene \\
1018Fw & TCTGGGYTGTTYCCCT & $855-872$ & Sequencing, 23S rRNA gene \\
1037IRrm97 & GGGGGTAGAGCACTGTTT & $1934-1954$ & Sequencing, 23S rRNA gene \\
1027VIR & CTTACCCGACAAGGAATTTCG & $1608-1623$ & Sequencing, 23S rRNA gene \\
328IRvm97 & AAACCGACACAGGTRG & $1923-1945$ & Sequencing, 23S rRNA gene \\
1042GPHI & TCCTAAGGTAGCGAAATTCCTTG & $2490-2512$ & Sequencing, 23S rRNA gene \\
\hline
\end{tabular}




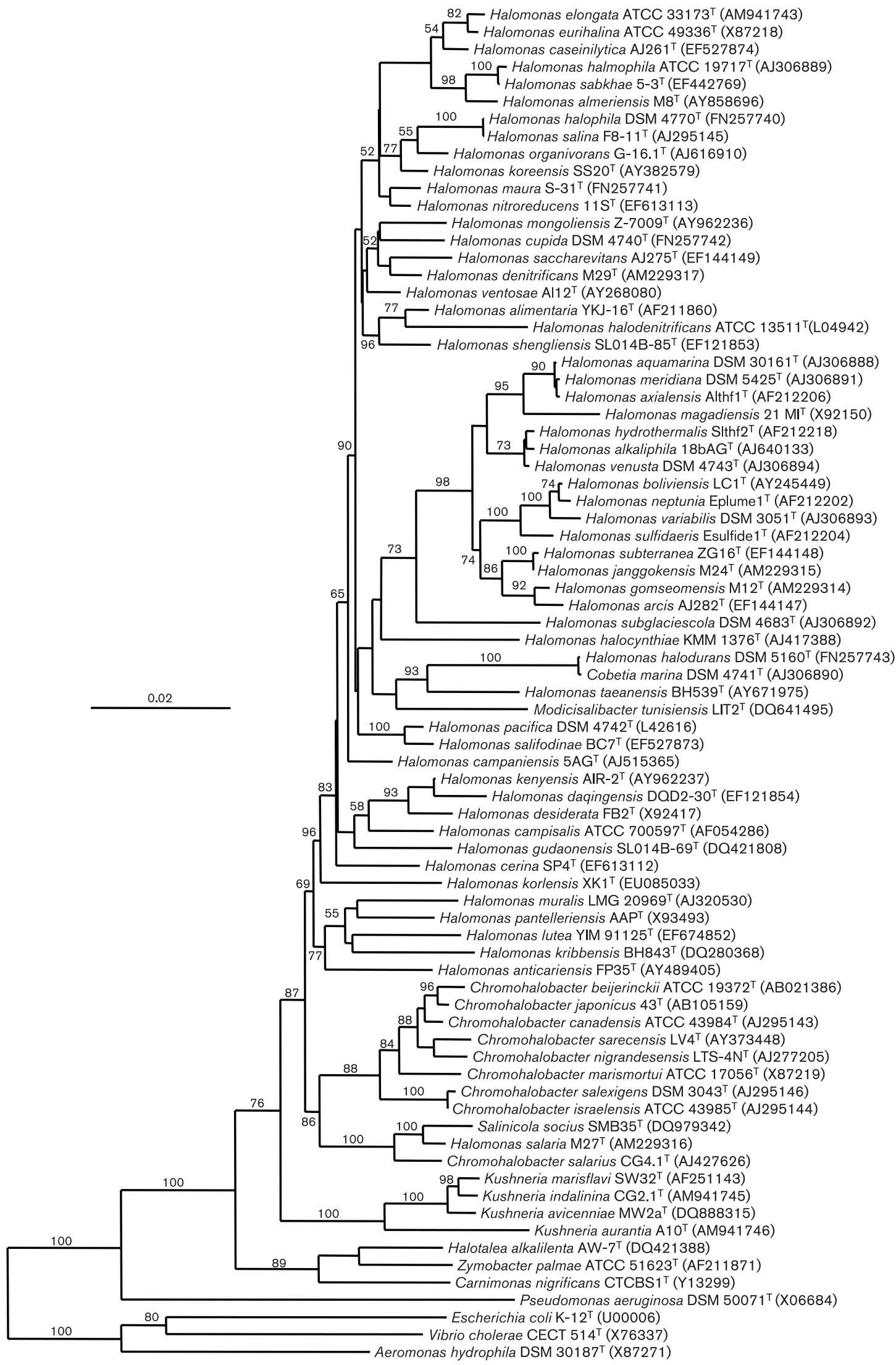


Fig. 1. Neighbour-joining phylogenetic tree, based on 16S rRNA gene sequence comparison, showing phylogenetic relationships between members of the family Halomonadaceae. Accession numbers are shown in parentheses. Bootstrap values $>50 \%$ are shown. Bar, 0.02 substitutions per nucleotide position.

adopting polyphasic approaches that integrate phenotypic (including chemotaxonomic markers) with genotypic methods (Arahal et al., 2007).

A second group of species of the genus Halomonas, designated group 2, includes the 16 species Halomonas aquamarina, $H$. meridiana, $H$. axialensis, $H$. magadiensis, $H$. hydrothermalis, $H$. alkaliphila, $H$. venusta, $H$. boliviensis,
H. neptunia, H. variabilis, $H$. sulfidaeris, $H$. subterranea, $H$. janggokensis, $H$. gomseomensis, $H$. arcis and $H$. subglaciescola. This group displays mean similarities of 97.4 and $97.5 \%$ for the $16 \mathrm{~S}$ and $23 \mathrm{~S}$ rRNA gene sequences, respectively. $H$. aquamarina DSM $30161^{\mathrm{T}}, H$. meridiana DSM $5425^{\mathrm{T}}$ and $H$. axialensis Althf $1^{\mathrm{T}}\left(=\mathrm{CECT} 5812^{\mathrm{T}}\right)$ form a fairly stable clade within this group with very similar 16S rRNA (99.9\%) and 23S rRNA (99.3-99.7\%)

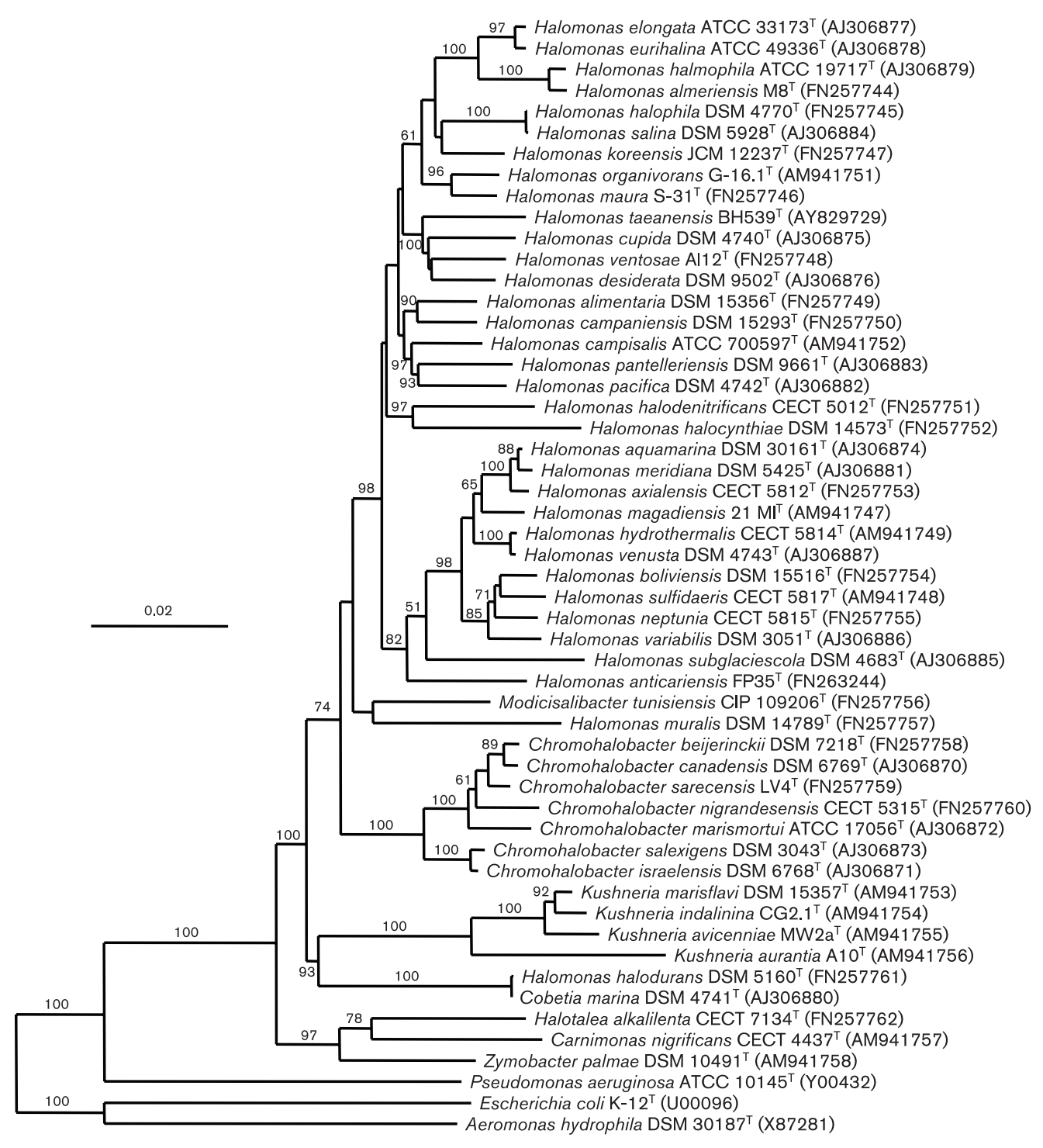

Fig. 2. Neighbour-joining phylogenetic tree, based on the $23 S$ rRNA gene sequence comparison, showing phylogenetic relationships between members of the family Halomonadaceae. Accession numbers are shown in parentheses. Bootstrap values $>50 \%$ are shown. Bar, 0.02 substitutions per nucleotide position. 
sequences. DNA-DNA hybridization values between the type strain of $H$. axialensis and those of $H$. aquamarina and H. meridiana was 28 and $32 \%$, respectively. Furthermore, $H$. axialensis is phenotypically different from the other two species (Kaye et al., 2004), supporting its taxonomic status as a distinct Halomonas species.

The values of sequence similarity between the strains included in group 1 and those belonging to group 2 were 96.1-93.2\% for the 16S rRNA gene and 95.3-93.5\% for the $23 \mathrm{~S}$ rRNA gene. These values would suggest that groups 1 and 2 of the genus Halomonas could constitute two different genera, with group 1 representing Halomonas sensu stricto since it contains the type species and therefore has priority to retain the name Halomonas. However, following the recommendations of Stackebrandt et al. (2002), the differentiation of taxa should be based on a polyphasic approach and sustained by phenotypic (including chemotaxonomic) features. Many attempts have been made to determine differential features between species of these two groups, but neither chemotaxonomic nor more general phenotypic studies have permitted their separation. All species belonging to groups 1 and 2 have phosphatidylglycerol and phosphatidylethanolamine as major polar lipids, ubiquinone 9 (except $H$. alkaliphila; Romano et al., 2006) as the respiratory quinone and $\mathrm{C}_{16: 0}$ and $\mathrm{C}_{18: 1} \omega 7 c$ (the latter not in $H$. alkaliphila; Romano et al., 2006) as fatty acids (Franzmann \& Tindall, 1990). In addition, species of groups 1 and 2 are catalase-positive and are strictly aerobic or facultatively anaerobic, oxidase-positive or -negative and may or may not be capable of reducing nitrates (Mata et al., 2002; Arahal \& Ventosa, 2006). In general, species from group 1 have a higher DNA G $+\mathrm{C}$ content (57-70 mol\%) than species from group 2 (51.4$62 \mathrm{~mol} \%$ ), and the former are more halophilic than the latter. Furthermore, all species belonging to group 2 are motile, while the species of group 1 are motile or nonmotile (Mata et al., 2002; Arahal \& Ventosa, 2006).

The other 27 species that are currently assigned to the genus Halomonas did not appear to be included clearly in either of these phylogenetic groups. One of these species, Halomonas salaria, always formed a separate group with the species Chromohalobacter salarius and the recently described Salinicola socius (Anan'ina et al., 2007). The $16 \mathrm{~S}$ rRNA gene sequence similarity between $H$. salaria $\mathrm{M} 27^{\mathrm{T}}$ and Chromohalobacter salarius CG $4.1^{\mathrm{T}}$ and $S$. socius $\mathrm{SMB}^{\mathrm{T}}{ }^{\mathrm{T}}$ was 98.4 and $98.7 \%$, respectively. The mean $16 \mathrm{~S}$ rRNA gene sequence similarity of this group to any of the Halomonas and Chromohalobacter species ranged from 93.0 to $96.4 \%$ and 93.6 to $96.5 \%$, respectively, values low enough as to justify their placement in a single genus. In addition, the mean similarity values obtained between the 16S rRNA gene sequences of these three species and those of the four species of Kushneria, Cobetia marina, Modicisalibacter tunisiensis, Zymobacter palmae, Carnimonas nigrificans and Halotalea alkalilenta were also very low (91.2-93.9, 94.3-95.2, 93.9-94.5, 93.0-93.4, 92.393.0 and $93.5-94.1 \%$, respectively). The phylogenetic coherence of these three species, Chromohalobacter salarius, H. salaria and S. socius, was also indicated by their recovery as a cluster in all trees generated from the bootstrapped dataset (Fig. 1 and Supplementary Figs S1 and S2). On the basis of these results, a reconsideration of their taxonomic status seems necessary.

On the other hand, Halomonas halodurans DSM $5160^{\mathrm{T}}$ constituted a very robust and stable cluster with Cobetia marina DSM $4741^{\mathrm{T}}$, the only species described to date within the genus Cobetia (Arahal et al., 2002a). The 16S and $23 \mathrm{~S}$ rRNA gene sequence similarities between these two strains were $100 \%$. However, when the $16 \mathrm{~S}$ and $23 \mathrm{~S}$ rRNA gene sequences of $H$. halodurans DSM $5160^{\mathrm{T}}$ were compared to those of the species of the genera Halomonas, Chromohalobacter, Modicisalibacter, Halotalea, Zymobacter, Carnimonas, Kushneria and Salinicola, the similarity values were always very low (91.8-95.8 and 89.3-93.8\%, respectively). Cobetia marina was first described as 'Arthrobacter marinus' by Cobet et al. (1970) and later proposed as Pseudomonas marina in an extensive study dealing with marine micro-organisms (Baumann et al., 1972). In 1983, it was reclassified within the genus Deleya (Baumann et al., 1983 ) and it was later moved again, to the genus Halomonas (Dobson \& Franzmann, 1996). Finally, on the basis of comparative $16 \mathrm{~S}$ and 23S rRNA gene phylogenetic analyses, as well as on phenotypic features, Arahal et al. (2002a) proposed the transfer of this species to the new genus Cobetia. From our data, there is not sufficient evidence to determine whether $H$. halodurans DSM $5160^{\mathrm{T}}$ and Cobetia marina DSM $4741^{\mathrm{T}}$ are members of the same or different species and thus an extensive study to compare these two species is required in order to define their taxonomic delineation.

It is also important to mention that the species Halomonas muralis, Halomonas pantelleriensis, Halomonas lutea and Halomonas kribbensis clustered together in all three $16 \mathrm{~S}$ rRNA gene-based trees (Fig. 1 and Supplementary Figs S1 and S2), but this is not a robust branch, since it was not conserved when 23S rRNA gene sequence analysis was performed (Fig. 1 and Supplementary Figs S1 and S2). On the other hand, Halomonas anticariensis could be included in group 2 of the genus Halomonas based on the 23S rRNA gene, but the 16S rRNA gene sequence study reveals that it is located far away from other Halomonas species. A possible explanation for these different topologies is that a recombination event might have occurred in the $23 \mathrm{~S}$ or $16 \mathrm{~S}$ rRNA gene.

As mentioned previously by Lee et al. (2005), phylogenetic analysis based on $16 \mathrm{~S}$ rRNA gene sequences showed that the species Halomonas taeanensis clustered together with Cobetia marina. Nevertheless, phylogenetic analysis based on $23 \mathrm{~S}$ rRNA gene sequences as well as $23 \mathrm{~S}$ and $16 \mathrm{~S}$ rRNA gene sequence similarity values $(96.9 \%$ with Halomonas ventosae $\mathrm{Al} 12^{\mathrm{T}}$ and $97.1 \%$ with Halomonas salifodinae $\mathrm{BC}^{\mathrm{T}}$, respectively) showed that $H$. taeanensis was more closely related to the genus Halomonas than to the genus Cobetia. 
With respect to the genus Chromohalobacter, all the species described to date clustered together (the mean $16 \mathrm{~S}$ and $23 \mathrm{~S}$ rRNA gene sequence similarity of this group was 98.0 and $97.8 \%$, respectively) with the only exception being Chromohalobacter salarius, as discussed previously.

Based on 16S rRNA gene sequence analysis and phenotypic evidence, Ben Ali Gam et al. (2007) proposed the creation of the genus Modicisalibacter with the new species Modicisalibacter tunisiensis in the family Halomonadaceae. However, after analysing the $23 \mathrm{~S}$ rRNA gene sequence of the type strain of this species, we found that it is located within group 1 of Halomonas (maximum-parsimony and maximum-likelihood trees; Supplementary Figs S1 and S2). Our hypothesis is that horizontal gene transfer might have occurred with another species of the genus Halomonas.

The phylogenetic distinctness of the remaining genera currently included in the family Halomonadaceae (Modicisalibacter, Halotalea, Zymobacter, Carnimonas, Cobetia, Kushneria and Salinicola) was confirmed in this study, being stable in the trees produced from all methods of analysis.

The 16S rRNA signature nucleotide characteristics of the family Halomonadaceae were defined by Ben Ali Gam et al. (2007). Since then, new genera and species within the family have been described, but the $16 \mathrm{~S}$ rRNA signature nucleotides that define the family have not changed: positions $484(\mathrm{~A} / \mathrm{G})$, $486(\mathrm{C} / \mathrm{U}), 640(\mathrm{~A} / \mathrm{G}), 660(\mathrm{~A}), 668(\mathrm{~A}), 669(\mathrm{~A}), 737(\mathrm{U})$, 738 (U), 745 (U), 776 (U), 1124 (U/G), 1297 (U), 1298 (C), $1423(\mathrm{~A}), 1424(\mathrm{C} / \mathrm{U}), 1439(\mathrm{U} / \mathrm{C}), 1462(\mathrm{~A} / \mathrm{G})$ and $1464(\mathrm{C} /$ $\mathrm{U})$. This feature has been used in some studies as a key for differentiation of genera within the Halomonadaceae. However, it must be taken into consideration that this is an arbitrary feature that must be revised when new isolates are characterized and often requires emended descriptions of the genera (Ntougias et al., 2007; Ben Ali Gam et al., 2007). If the $16 \mathrm{~S}$ rRNA sequence is to be used as a delineating trait at the rank of family or any other, it makes much more sense to use (almost) complete sequences and not only a few nucleotides.

In conclusion, we found that, although the resolution of the 23S rRNA gene sequence within the family Halomonadaceae is generally greater than that of the $16 \mathrm{~S}$ rRNA sequence, it still does not allow resolution of the phylogenetic relationships of very closely related species. Furthermore, the continuous and rapid increase in the number of genera and species within this family makes it even more complicated. To overcome these limitations, the inclusion of further housekeeping genes, resulting in a multilocus sequencing analysis (MLSA), may help to clarify the phylogenetic relationships between the members of this heterogeneous family. In an attempt to carry out an MLSA of the species $H$. variabilis, Okamoto et al. (2004) determined the sequences of $\operatorname{gyr} B, e c t B$ and $e c t C$ genes of ten strains of $H$. variabilis, finding that phylogenetic trees based on $\operatorname{gyr} B$ and ectB genes were very similar to that based on the 16S rRNA gene, but the ectC-based tree was inconsistent with the other topologies.

\section{Acknowledgements}

R.R.d.l.H. was a recipient of a fellowship from the Spanish Ministerio de Educación y Ciencia. We thank Dr Paul de Vos for advice and Dr R. Thane Papke for critical reading of the manuscript. This study was supported by grants from the Spanish Ministerio de Educación y Ciencia (BIO2006-06927) and the Junta de Andalucía (P06-CVI-01829).

\section{References}

Aguilera, M., Cabrera, A., Incerti, C., Fuentes, S., Russell, N. J., Ramos-Cormenzana, A. \& Monteoliva-Sánchez, M. (2007). Chromohalobacter salarius sp. nov., a moderately halophilic bacterium isolated from a solar saltern in Cabo de Gata, Almería, southern Spain. Int J Syst Evol Microbiol 57, 1238-1242.

Anan'ina, L. N., Plotnikova, E. G., Gavrish, E. Y., Demako, V. A. \& Evtushenko, L. I. (2007). Salinicola socius gen. nov., sp. nov., a moderately halophilic bacterium from a naphthalene-utilizing microbial association. Microbiology (English translation of Mikrobiologiia) 76, 324-330.

Anan'ina, L. N., Plotnikova, E. G., Gavrish, E. Y., Demako, V. A. \& Evtushenko, L. I. (2008). Salinicola socius gen. nov., sp. nov. In List of New Names and New Combinations Previously Effectively, but not Validly, Published, Validation List no. 124. Int J Syst Evol Microbiol 58, 2471-2472.

Arahal, D. R. \& Ventosa, A. (2006). The family Halomonadaceae. In The Prokaryotes: a Handbook on the Biology of Bacteria, 3rd edn, vol. 6, pp. 811-835. Edited by M. Dworkin, S. Falkow, E. Rosenberg, K. H. Schleifer \& E. Stackebrandt. New York: Springer.

Arahal, D. R., Garcia, M. T., Ludwig, W., Schleifer, K. H. \& Ventosa, A. (2001a). Transfer of Halomonas canadensis and Halomonas israelensis to the genus Chromohalobacter as Chromohalobacter canadensis comb. nov. and Chromohalobacter israelensis comb. nov. Int J Syst Evol Microbiol 51, 1443-1448.

Arahal, D. R., García, M. T., Vargas, C., Cánovas, D., Nieto, J. J. \& Ventosa, A. (2001b). Chromohalobacter salexigens sp. nov., a moderately halophilic species that includes Halomonas elongata DSM 3043 and ATCC 33174. Int J Syst Evol Microbiol 51, 14571462.

Arahal, D. R., Castillo, A. M., Ludwig, W., Schleifer, K. H. \& Ventosa, A. (2002a). Proposal of Cobetia marina gen. nov., comb. nov., within the family Halomonadaceae, to include the species Halomonas marina. Syst Appl Microbiol 25, 207-211.

Arahal, D. R., Ludwig, W., Schleifer, K. H. \& Ventosa, A. (2002b). Phylogeny of the family Halomonadaceae based on $23 \mathrm{~S}$ and $16 \mathrm{~S}$ rRNA sequence analyses. Int J Syst Evol Microbiol 52, 241-249.

Arahal, D. R., Vreeland, R. H., Litchfield, C. D., Mormile, M. R., Tindall, B. J., Oren, A., Bejar, V., Quesada, E. \& Ventosa, A. (2007). Recommended minimal standards for describing new taxa of the family Halomonadaceae. Int J Syst Evol Microbiol 57, 2436-2446.

Baumann, L., Baumann, P., Mandel, M. \& Allen, R. D. (1972). Taxonomy of aerobic marine eubacteria. J Bacteriol 110, 402-429.

Baumann, L., Bowditch, R. D. \& Baumann, P. (1983). Description of Deleya gen. nov. created to accommodate the marine species Alcaligenes aestus, A. pacificus, A. cupidus, A. venustus, and Pseudomonas marina. Int J Syst Bacteriol 33, 793-802.

Ben Ali Gam, Z., Abdelkafi, S., Casalot, L., Tholozan, J. L., Oueslati, R. \& Labat, M. (2007). Modicisalibacter tunisiensis gen. nov., sp. nov., an aerobic, moderately halophilic bacterium isolated from an oilfieldwater injection sample, and emended description of the family Halomonadaceae Franzmann et al. 1989 emend. Dobson and 
Franzmann 1996 emend. Ntougias et al. 2007. Int J Syst Evol Microbiol 57, 2307-2313.

Berendes, F., Gottschalk, G., Heine-Dobbernack, E., Moore, E. R. B. \& Tindall, B. J. (1996). Halomonas desiderata sp. nov., a new alkaliphilic, halotolerant and denitrifying bacterium isolated from a municipal sewage works. Syst Appl Microbiol 19, 158-167.

Boltyanskaya, Y. V., Kevbrin, V. V., Lysenko, A. M., Kolganova, T. V., Tourova, T. P., Osipov, G. A. \& Zhilina, T. N. (2007). Halomonas mongoliensis sp. nov. and Halomonas kenyensis sp. nov., new haloalkaliphilic denitrifiers capable of $\mathrm{N}_{2} \mathrm{O}$ reduction, isolated from soda lakes. Microbiology (English translation of Mikrobiologiia) 76, 739-747.

Bouchotroch, S., Quesada, E., del Moral, A., Llamas, I. \& Béjar, V. (2001). Halomonas maura sp. nov., a novel moderately halophilic, exopolysaccharide-producing bacterium. Int J Syst Evol Microbiol 51, 1625-1632.

Cobet, A. B., Wirsen, C. \& Jones, G. E. (1970). The effect of nickel on a marine bacterium, Arthrobacter marinus sp. nov. J Gen Microbiol 62, 159-169.

Dobson, S. J. \& Franzmann, P. D. (1996). Unification of the genera Deleya (Baumann et al. 1983), Halomonas (Vreeland et al. 1980), and Halovibrio (Fendrich 1988) and the species Paracoccus halodenitrificans (Robinson and Gibbons 1952) into a single genus, Halomonas, and placement of the genus Zymobacter in the family Halomonadaceae. Int J Syst Bacteriol 46, 550-558.

Dobson, S. J., James, S. R., Franzmann, P. D. \& McMeekin, T. A. (1990). Emended description of Halomonas halmophila (NCMB $1971^{\mathrm{T}}$ ). Int J Syst Bacteriol 40, 462-463.

Dobson, S. J., McMeekin, T. A. \& Franzmann, P. D. (1993). Phylogenetic relationships between some members of the genera Deleya, Halomonas, and Halovibrio. Int J Syst Bacteriol 43, 665-673.

Duckworth, A. W., Grant, W. D., Jones, B. E., Meijer, D., Márquez, M. C. \& Ventosa, A. (2000). Halomonas magadii sp. nov., a new member of the genus Halomonas, isolated from a soda lake of the East African rift valley. Extremophiles 4, 53-60.

Felsenstein, J. (1981). Evolutionary trees from DNA sequences: a maximum likelihood approach. J Mol Evol 17, 368-376.

Fendrich, C. (1988). Halovibrio variabilis gen. nov., sp. nov., Pseudomonas halophila sp. nov. and a new halophilic aerobic coccoid Eubacterium from Great Salt Lake, Utah, USA. Syst Appl Microbiol 11, $36-43$.

Fitch, W. M. (1971). Toward defining the course of evolution: minimum change for a specific tree topology. Syst Zool 20, 406-416.

Franzmann, P. D. \& Tindall, B. J. (1990). A chemotaxonomic study of members of the family Halomonadaceae. Syst Appl Microbiol 13, 142147.

Franzmann, P. D., Burton, H. R. \& McMeekin, T. A. (1987). Halomonas subglaciescola, a new species of halotolerant bacteria isolated from Antarctica. Int J Syst Bacteriol 37, 27-34.

Franzmann, P. D., Wehmeyer, U. \& Stackebrandt, E. (1988). Halomonadaceae fam. nov., a new family of the class Proteobacteria to accommodate the genera Halomonas and Deleya. Syst Appl Microbiol 11, 16-19.

García, M. T., Mellado, E., Ostos, J. C. \& Ventosa, A. (2004). Halomonas organivorans sp. nov., a moderate halophile able to degrade aromatic compounds. Int J Syst Evol Microbiol 54, 17231728.

Garriga, M., Ehrmann, M. A., Arnau, J., Hugas, M. \& Vogel, R. F. (1998). Carnimonas nigrificans gen. nov., sp. nov., a bacterial causative agent for black spot formation on cured meat products. Int J Syst Bacteriol 48, 677-686.
González-Domenech, C. M., Béjar, V., Martínez-Checa, F. \& Quesada, E. (2008a). Halomonas nitroreducens sp. nov., a novel nitrate- and nitrite-reducing species. Int J Syst Evol Microbiol 58, 872876.

González-Domenech, C. M., Martínez-Checa, F., Quesada, E. \& Béjar, V. (2008b). Halomonas cerina sp. nov., a moderately halophilic, denitrifying, exopolysaccharide-producing bacterium. Int J Syst Evol Microbiol 58, 803-809.

Hebert, A. M. \& Vreeland, R. H. (1987). Phenotypic comparison of halotolerant bacteria: Halomonas halodurans sp. nov., nom. rev., comb. nov. Int J Syst Bacteriol 37, 347-350.

Heyrman, J., Balcaen, A., De Vos, P. \& Swings, J. (2002). Halomonas muralis sp. nov., isolated from microbial biofilms colonizing the walls and murals of the Saint-Catherine chapel (Castle Herberstein, Austria). Int J Syst Evol Microbiol 52, 2049-2054.

James, S. R., Dobson, S. J., Franzmann, P. D. \& McMeekin, T. A. (1990). Halomonas meridiana, a new species of extremely halotolerant bacteria isolated from Antarctic saline lakes. Syst Appl Microbiol 13, 270-277.

Jeon, C. O., Lim, J. M., Lee, J. R., Lee, G. S., Park, D. J., Lee, J. C., Oh, H. W. \& Kim, C. J. (2007). Halomonas kribbensis sp. nov., a novel moderately halophilic bacterium isolated from a solar saltern in Korea. Int J Syst Evol Microbiol 57, 2194-2198.

Jukes, T. H. \& Cantor, C. R. (1969). Evolution of protein molecules. In Mammalian Protein Metabolism, vol. 3, pp. 21-132. Edited by H. N. Munro. New York: Academic Press.

Kaye, J. Z., Márquez, M. C., Ventosa, A. \& Barros, J. A. (2004). Halomonas neptunia sp. nov., Halomonas sulfidaeris sp. nov., Halomonas axialensis sp. nov. and Halomonas hydrothermalis sp. nov.: halophilic bacteria isolated from deep-sea hydrothermal-vent environments. Int J Syst Evol Microbiol 54, 499-511.

Kharroub, K., Jiménez-Pranteda, M. L., Aguilera, M., Boulahrouf, A., Ramos-Cormenzana, A. \& Monteoliva-Sánchez, M. (2008). Halomonas sabkhae sp. nov., a moderately halophilic bacterium isolated from an Algerian sabkha. Int J Syst Evol Microbiol 58, 40-44.

Kim, K. K., Jin, L., Yang, H. C. \& Lee, S.-T. (2007). Halomonas gomseomensis sp. nov., Halomonas janggokensis sp. nov., Halomonas salaria sp. nov. and Halomonas denitrificans sp. nov., moderately halophilic bacteria isolated from saline water. Int J Syst Evol Microbiol 57, 675-681.

Lee, J.-C., Jeon, C. O., Lim, J.-M., Lee, S.-M., Lee, J.-M., Song, S.-M., Park, D.-J., Li, W.-J. \& Kim, C.-J. (2005). Halomonas taeanensis sp. nov., a novel moderately halophilic bacterium isolated from a solar saltern in Korea. Int J Syst Evol Microbiol 55, 2027-2032.

Li, H.-B., Zhang, L.-P. \& Chen, S.-F. (2008). Halomonas korlensis sp. nov., a moderately halophilic denitrifying bacterium isolated from saline and alkaline soil. Int J Syst Evol Microbiol 58, 2582-2588.

Lim, J.-M., Yoon, J.-H., Lee, J.-C., Jeon, C. O., Park, D.-J., Sung, C. \& Kim, C.-J. (2004). Halomonas koreensis sp. nov., a novel moderately halophilic bacterium isolated from a solar saltern in Korea. Int J Syst Evol Microbiol 54, 2037-2042.

Ludwig, W., Strunk, O., Klugbauer, S., Klugbauer, N., Weizenegger, M., Neumaier, J., Bachleitner, M. \& Schleifer, K. H. (1998). Bacterial phylogeny based on comparative sequence analysis. Electrophoresis 19, 554-568.

Ludwig, W., Strunk, O., Westram, R., Richter, L., Meier, H., Yadhukumar, Buchner, A., Lai, T., Steppi, S. \& other authors (2004). ARB: a software environment for sequence data. Nucleic Acids Res 32, 1363-1371.

Martínez-Cánovas, M. J., Quesada, E., Llamas, I. \& Béjar, V. (2004a). Halomonas ventosae sp. nov., a moderately halophilic, denitrifying, 
exopolysaccharide-producing bacterium. Int J Syst Evol Microbiol 54, 733-737.

Martínez-Cánovas, M. J., Béjar, V., Martínez-Checa, F. \& Quesada, E. (2004b). Halomonas anticariensis sp. nov., from Fuente de Piedra, a saline-wetland wildfowl reserve in Málaga, southern Spain. Int J Syst Evol Microbiol 54, 1329-1332.

Martínez-Checa, F., Béjar, V., Martínez-Cánovas, M. J., Llamas, I. \& Quesada, E. (2005). Halomonas almeriensis sp. nov., a moderately halophilic, exopolysaccharide-producing bacterium from Cabo de Gata, Almería, south-east Spain. Int J Syst Evol Microbiol 55, 20072011.

Mata, J. A., Martínez-Cánovas, J., Quesada, E. \& Béjar, V. (2002). A detailed phenotypic characterisation of the type strains of Halomonas species. Syst Appl Microbiol 25, 360-375.

Mellado, E., Moore, E. R. B., Nieto, J. J. \& Ventosa, A. (1995). Phylogenetic inferences and taxonomic consequences of $16 \mathrm{~S}$ ribosomal DNA sequence comparison of Chromohalobacter marismortui, Volcaniella eurihalina, and Deleya salina and reclassification of $V$. eurihalina as Halomonas eurihalina comb. nov. Int $J$ Syst Bacteriol 45, 712-716.

Mormile, M. R., Romine, M. F., García, M. T., Ventosa, A., Bailey, T. J. \& Peyton, B. M. (1999). Halomonas campisalis sp. nov., a denitrifying, moderately haloalkaliphilic bacterium. Syst Appl Microbiol 22, 551558.

Ntougias, S., Zervakis, G. I. \& Fasseas, C. (2007). Halotalea alkalilenta gen. nov., sp. nov., a novel osmotolerant and alkalitolerant bacterium from alkaline olive mill wastes, and emended description of the family Halomonadaceae Franzmann et al. 1989, emend. Dobson and Franzmann 1996. Int J Syst Evol Microbiol 57, 1975-1983.

Okamoto, T., Taguchi, H., Nakamura, K., Ikenaga, H., Kuraishi, H. \& Yamasato, K. (1993). Zymobacter palmae gen. nov., sp. nov., a new ethanol-fermenting peritrichous bacterium isolated from palm sap. Arch Microbiol 160, 333-337.

Okamoto, T., Maruyama, A., Imura, S., Takeyama, H. \& Naganuma, T. (2004). Comparative phylogenetic analyses of Halomonas variabilis and related organisms based on $16 \mathrm{~S}$ rRNA, gyrB and ectBC gene sequences. Syst Appl Microbiol 27, 323-333.

Peçonek, J., Gruber, C., Gallego, V., Ventosa, A., Busse, H.-J., Kämpfer, P., Radax, C. \& Stan-Lotter, H. (2006). Reclassification of Pseudomonas beijerinckii Hof 1935 as Chromohalobacter beijerinckii comb. nov., and emended description of the species. Int J Syst Evol Microbiol 56, 1953-1957.

Prado, B., Lizama, C., Aguilera, M., Ramos-Cormenzana, A., Fuentes, S., Campos, V. \& Monteoliva-Sánchez, M. (2006). Chromohalobacter nigrandesensis sp. nov., a moderately halophilic, Gram-negative bacterium isolated from Lake Tebenquiche on the Atacama Saltern, Chile. Int J Syst Evol Microbiol 56, 647651.

Pruesse, E., Quast, C., Knittel, K., Fuchs, B., Ludwig, W., Peplies, J. \& Glöckner, F. O. (2007). SILVA: a comprehensive online resource for quality checked and aligned ribosomal RNA sequence data compatible with ARB. Nucleic Acids Res 35, 7188-7196.

Quillaguamán, J., Hatti-Kaul, R., Mattiasson, B., Alvarez, M. T. \& Delgado, O. (2004a). Halomonas boliviensis sp. nov., an alkalitolerant, moderate halophile isolated from soil around a Bolivian hypersaline lake. Int J Syst Evol Microbiol 54, 721-725.

Quillaguamán, J., Delgado, O., Mattiasson, B. \& Hatti-Kaul, R. (2004b). Chromohalobacter sarecensis sp. nov., a psychrotolerant moderate halophile isolated from the saline Andean region of Bolivia. Int J Syst Evol Microbiol 54, 1921-1926.

Romanenko, L. A., Schumann, P., Rohde, M., Mikhailov, V. V. \& Stackebrandt, E. (2002). Halomonas halocynthiae sp. nov., isolated from the marine ascidian Halocynthia aurantium. Int J Syst Evol Microbiol 52, 1767-1772.

Romano, I., Nicolaus, B., Lama, L., Manca, M. C. \& Gambacorta, A. (1996). Characterization of a haloalkalophilic strictly aerobic bacterium, isolated from Pantelleria island. Syst Appl Microbiol 19, 326-333.

Romano, I., Giordano, A., Lama, L., Nicolaus, B. \& Gambacorta, A. (2005). Halomonas campaniensis sp. nov., a haloalkaliphilic bacterium isolated from a mineral pool of Campania Region, Italy. Syst Appl Microbiol 28, 610-618.

Romano, I., Lama, L., Nicolaus, B., Poli, A., Gambacorta, A. \& Giordano, A. (2006). Halomonas alkaliphila sp. nov., a novel halotolerant alkaliphilic bacterium isolated from a salt pool in Campania (Italy). J Gen Appl Microbiol 52, 339-348.

Saitou, N. \& Nei, M. (1987). The neighbor-joining method: a new method for reconstructing phylogenetic trees. Mol Biol Evol 4, 406425.

Sambrook, J. \& Russell, D. W. (2001). Molecular Cloning: a Laboratory Manual, 3rd edn. Cold Spring Harbor, NY: Cold Spring Harbor Laboratory.

Sánchez-Porro, C., Tokunaga, H., Tokunaga, M. \& Ventosa, A. (2007). Chromohalobacter japonicus sp. nov., a moderately halophilic bacterium isolated from a Japanese salty food. Int J Syst Evol Microbiol 57, 2262-2266.

Sánchez-Porro, C., de la Haba, R. R., Soto-Ramírez, N., Márquez, M. C., Montalvo-Rodríguez, R. \& Ventosa, A. (2009). Description of Kushneria aurantia gen. nov., sp. nov., a novel member of the family Halomonadaceae, and a proposal for reclassification of Halomonas marisflavi as Kushneria marisflavi comb. nov., of Halomonas indalinina as Kushneria indalinina comb. nov. and of Halomonas avicenniae as Kushneria avicenniae comb. nov. Int J Syst Evol Microbiol 59, 397-405.

Stackebrandt, E., Frederiksen, W., Garrity, G. M., Grimont, P. A. D., Kämpfer, P., Maiden, M. C. J., Nesme, X., Rosselló-Mora, R., Swings, J. \& other authors (2002). Report of the ad hoc committee for the re-evaluation of the species definition in bacteriology. Int $J$ Syst Evol Microbiol 52, 1043-1047.

Valderrama, M. J., Quesada, E., Bejar, V., Ventosa, A., Gutierrez, M. C., Ruiz-Berraquero, F. \& Ramos-Cormenzana, A. (1991). Deleya salina sp. nov., a moderately halophilic Gram-negative bacterium. Int J Syst Bacteriol 41, 377-384.

Ventosa, A., Gutiérrez, M. C., García, M. T. \& Ruiz-Berraquero, F. (1989). Classification of "Chromobacterium marismortui" in a new genus, Chromohalobacter gen. nov., as Chromohalobacter marismortui comb. nov., nom. rev. Int J Syst Bacteriol 39, 382-386.

Vreeland, R. H., Litchfield, C. D., Martin, E. L. \& Elliot, E. (1980). Halomonas elongata, a new genus and species of extremely salttolerant bacteria. Int J Syst Bacteriol 30, 485-495.

Wang, Y.-N., Cai, H., Yu, S.-L., Wang, Z.-Y., Liu, J. \& Wu, X.-L. (2007a). Halomonas gudaonensis sp. nov., isolated from a saline soil contaminated by crude oil. Int J Syst Evol Microbiol 57, 911-915.

Wang, Y.-N., Cai, H., Chi, C.-Q., Lu, A.-H., Lin, X.-G., Jiang, Z.-F. \& Wu, X.-L. (2007b). Halomonas shengliensis sp. nov., a moderately halophilic, denitrifying, crude-oil-utilizing bacterium. Int J Syst Evol Microbiol 57, 1222-1226.

Wang, Y., Tang, S.-K., Lou, K., Mao, P.-H., Jin, X., Jiang, C.-L., Xu, L.-H. \& Li, W.-J. (2008a). Halomonas lutea sp. nov., a moderately halophilic bacterium isolated from a salt lake. Int J Syst Evol Microbiol 58, 20652069.

Wang, Y., Wu, Y.-H., Wang, C.-S., Xu, X.-W., Oren, A., Zhu, X.-F. \& Wu, M. (2008b). Halomonas salifodinae sp. nov., a halophilic bacterium isolated from a salt mine in China. Int J Syst Evol Microbiol 58, 2855-2858. 
Wu, Y. H., Xu, X. W., Huo, Y. Y., Zhou, P., Zhu, X. F., Zhang, H. B. \& Wu, M. (2008a). Halomonas caseinilytica sp. nov., a halophilic bacterium isolated from a saline lake on the Qinghai-Tibet Plateau, China. Int J Syst Evol Microbiol 58, 1259-1262.

Wu, G., Wu, X.-O., Wang, Y.-N., Chi, C.-Q., Tang, Y.-O., Kida, K., Wu, X.-L. \& Luan, Z.-K. (2008b). Halomonas daqingensis sp. nov., a moderately halophilic bacterium isolated from an oilfield soil. Int $J$ Syst Evol Microbiol 58, 2859-2865.
Xu, X. W., Wu, Y. H., Zhou, Z., Wang, C. S., Zhou, Y. G., Zhang, H. B., Wang, Y. \& Wu, M. (2007). Halomonas saccharevitans sp. nov., Halomonas arcis sp. nov. and Halomonas subterranea sp. nov., halophilic bacteria isolated from hypersaline environments of China. Int J Syst Evol Microbiol 57, 1619-1624.

Yoon, J.-H., Lee, K.-C., Kho, Y. H., Kang, K. H., Kim, C.-J. \& Park, Y.-H. (2002). Halomonas alimentaria sp. nov., isolated from jeotgal, a traditional Korean fermented seafood. Int J Syst Evol Microbiol 52, 123-130. 